\title{
MODEL POLICY DESIGN FOR THE BEEF CATTLE DEVELOPMENT IN SOUTH SULAWESI
}

\author{
Machmud Achmad \\ School of Management and Business \\ Bogor Agricultural University \\ Sri Hartoyo \\ School of Management and Business \\ Bogor Agricultural University \\ Bustanul Arifin \\ Lampung University \\ Muhammad Said Didu \\ Institution for Research and Technology Implementation
}

This study examines some factors that influence policies on developing cattle beef and designing integrated planning systems in South Sulawesi. The method for this study includes qualitative and quantitative approaches using survey method to obtain primary data. Data were analysed and presented in the form of descriptive tables and graphs with analytical tools policy. Results were obtained from choices of recommendations which are elaborated in the form of strategy and policy implications based on expert opinions (expert judgment). Internal and External Matrices were generated by the SWOT analysis and the QSPM. The results show that current position of beef cattle in South Sulawesi is in the quadrant of growth and development. Analysing all the factors from SWOT approach, four strategies were developed to determine the beef cattle policy strategy. Using the QSPM, the results further suggest that the best strategy is priority strategy as seen from its QSPM value of 6,901.An integrated system between the beef cattle rancher and crop (rice and corn), implies that in order to achieve this goal, technology improvement and innovation play important roles, especially technology for the feed processing system.

Keywords:

Beef cattle, IFE EFE matrix, SWOT and QSPM, South Sulawesi 


\section{INTRODUCTION}

Animal husbandry is part of the agricultural sectors that represents the important sub-sector to support the people's economy. Livestock commodities have very good prospect to be developed; an example would be the Beef cattle industry which produces protein-rich meat. The reason for beef cattle development is because of the advantages of local resources that exist in different parts of Indonesia. Dwiyanto et al. (2005) noted several problems in the development of beef cattle in Indonesia, among the obstacles are: (i) Low livestock productivity, (ii) Limited local cattle availability, (iii) Lack productivity and low level of knowledge, (iv) Uncertainty of feed supply especially during dry season, (v) Less optimal farm system, and (vi) inefficient marketing.

South Sulawesi Province Office of Livestock Services will launch a program entitled "Programs to achieve 2 million targeted cattle population toward 2016 in supporting the national program for selfsufficiency in beef meat for 2014". This is consistent with province's mission and vision to become the main supplier of beef cattle and cows. Such vision implies that livestock program may increase the population and genetic quality of cattle. Furthermore, those genetic cattles are expected to have similar quality as the local cattle.

Various problems in beef breeding/agribusiness have been encountered in South Sulawesi. Among the problems are: (i) the declining number of cattle and buffalo population which due to high slaughter rate of the productive cows and lack of interest of the farmers, (ii) limited smallholders production in which beef cattle business is regarded as a sideline core farm activity and only a small percentage of the people make it as the source of their income, (iii) low quality of livestock products, (iv) lack of capital, and (v) institutional weaknesses especially at the level of smallholders and farmers (South Sulawesi Livestock Office, 2001). However, Bali cattle, which have been developed in South Sulawesi, have been proven to be well adapted to the local agro-climatic conditions. Furthermore, the Brahman and Limousine cattle were also raised to support the increase in number of beef cattle and cow population.

Beef cattle farming in Indonesia serves a very strategic function especially in providing employment opportunities for rural communities, as a producer of meat for human wellbeing and to meet customer needs, all of which are intended to improve the people's quality of life and of intellectual (Santosa 2006). Therefore, empowering rural communities through community-based beef cattle breeding is a necessary, particularly in the province of South Sulawesi. The achievement of Accelerated Beef Sufficiency Program (P2SDS) 2014 requires more support to establish steps in order to implement the program. This is the reason for the author to conduct the study.

The government has long enforced the policy of beef cattle development. A study by Nasution (1983) indicated that there had been two policies implemented for cattle development. The first policy put the emphasize on the increase number of cattle supported by the procurement of improved quality cows, disease prevention, business counselling and coaching, credit assistance, procurement and improvement of feed quality, marketing and partnership building with the stakeholders. The second one was implemented by increasing the economically viable production, supported by a particular combination through the use of superior cows and feed, as well as good management. 
Based on the background above, this study is aimed at (i) examining the existing characteristics of the cattle farmers, i.e. their social and economic characteristics in relation to the development of beef cattle farming, to determine factors influencing the policy of beef cattle farming, and (ii) designing the policy of beef cattle farming development in South Sulawesi. The study is intended (i) to contribute the development of science, particularly in management discipline and beef cattle business; (ii) to contribute data and information and ideas in relation to sustainable farm resource management planning; (iii) to provide inputs for policy makers, both at the central and local governments, and lastly (iv) to develop the management plan for beef cattle development in order to fulfill the national food security needs.

\section{LITERATURE REVIEW}

\section{$2.1 \quad$ Background}

In Indonesia, the development of beef cattle is carried out jointly by the government, communities (small scale farmers), and the private sectors. The government sets the rules, facilitates and oversees the supply and availability of products, quantity and quality, to meet the requirements of halal, safe, nutritious, and health concern while the private and public play their role in bringing about the adequacy of livestock products through the production, importation, processing, marketing, and distribution of beef cattle (Bamualim et al. 2008). According to Haryanto (2009), in order to increase the income and to protect the people's breeding farm, there are some policies measures that should take place and are imposed by the government. They include tariff, subsidies, capital, institutional, and maintenance system.
The policy needs to be analyzed and thus the analysis is the processes to synthesize mixed information, derived from the research, mass media or laws, which then formulate further a policies to encourage the advancement of agriculture and plantation. Therefore, it requires a comprehensive formulation to make it one of the driving forces of economic growth in Indonesia based on the economic results of the agricultural sector (Nugrohadi IAW, 2009).

$$
\text { In addition, according to Saragih }
$$

(2000), livestock-based agribusiness is a system that includes four subsystems; up stream, on-farming, down-stream agribusiness and supporting institutions. For animal husbandry in particular, livestock agribusiness is an integrated and comprehensive system of livestock management that covers all activities ranging from manufacturing and distribution of livestock production facilities, production activities (breeding), storage and processing, to the distribution and marketing of farm products, supported by the supporting institutions (Rahardi and Hartono, 2003).

\subsection{External Factor Evaluation (EFE) Matrix}

External Factor Evaluation (EFE) Matrix is used to evaluate the external factors that determine the success of a cattle rancher in competition. The relevant external data are collected for analysis. These external factors are related to economic, social, and cultural demography, environment, politic, government, legal system, technology, and competition in industrial cattle markets where the cattle rancher is located, and other relevant external data. This is important because external factors have direct or indirect influence on the cattle rancher. The external factors generated in this study are from planning documments of Dinas Peternakan 
(Animal Husbandry Office),and in depth interview with the expert and focus group discussion (FGD).

\subsection{Internal Factor Evaluation (IFE)}

Internal Factor Evaluation (IFE)

Matrix is used to determine the internal factors that affect the competitiveness of a cattle rancher, which deals with the strengths and weaknesses. Data and information on the internal aspects of the company can be obtained from rancher's functions, such as aspects of management, finance, human resources (HR), marketing, information systems, production and operation. The internal factors generated in this study are taken from depth interview with the expert in a group discussion.

\subsection{IE Matrix}

Internal-External (IE) matrix is used to evaluate external factors (opportunities and challenges) and internal factors (strengths and weaknesses) that result in a matrix form consisting of 9 cells that in principle can be grouped into 3 main strategies (David, 2009) namely:

a. Growth strategy is the company's growth (cells I, II and IV).

b. Stability strategy is a strategy adopted without changing the direction of the predetermined strategy. (cells III, V and VII).

c. Retrenchment strategy is an effort to minimize or reduce the work done by the company (cells VI, VIII, and IX).

The Internal-External (IE) Matrix is illustrated in Figure 1. below.

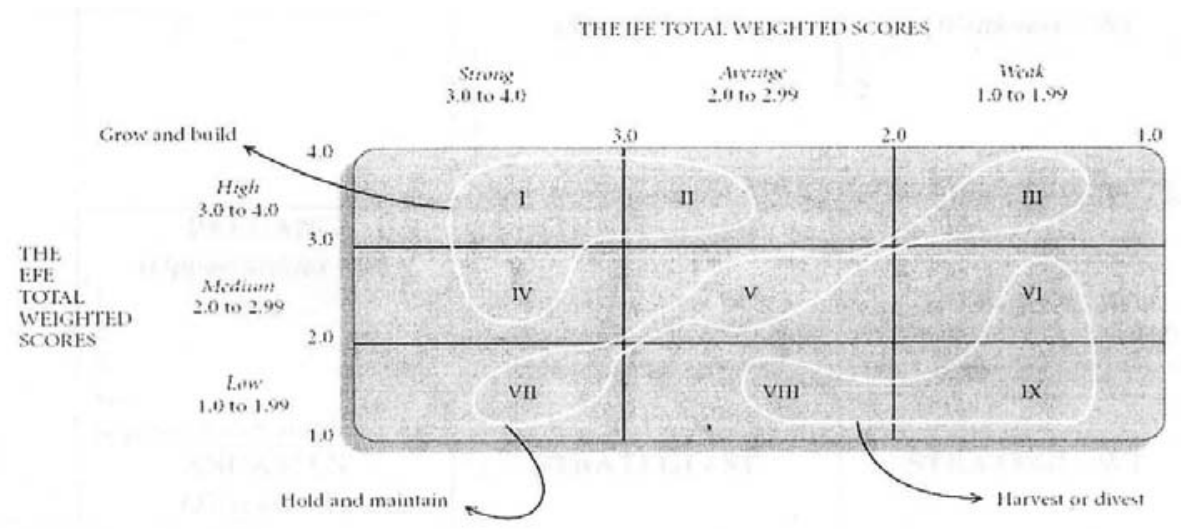

Source: David (2009)

Figure 1.

Internal-External (IE) Matrix

IE matrix is based on two key dimensions: EFI total weighted score on the horizontal axis and the EFE total weighted score on the vertical axis. Of the total weighted scores, each division IE Matrix at the corporate level can be composed. On the horizontal axis of IE Matrix, the EFI total weighted score from 1.0 to 1.99 indicates a weak internal position; score from 2.0 to 2 ,
99 is considered as moderate, and score of 3.0 to 4.0 is considered as strong. This hold true for vertical axis, where the EFE total weighted score of 1.0 to 1.99 is considered to be as low position while 2.0 to 2.99 as moderate, and 3.0 to 4.0 as high. 


\section{$2.5 \quad$ SWOT Analysis}

Another instrument analysis used in this study is the matrix of SWOT (StrengthsWeaknesses-Opportunities Threats). SWOT matrix combines the opportunities and threats that are being faced and can be further tailored according to the existing strengths and weaknesses to produce SO, WO, WT, or ST strategy.

SWOT Analysis is a powerful analytical instrument if used accordingly. The strength and weaknesses can be found in an organizational body, including particular business unit, while opportunities and threats are external factors that confront organizations, companies or business units in question (Siagian, 2004).

SWOT matrix scheme consists of four cells; four cells of main factors (external and internal factors) and four cells of strategy which combines internal and external factors (SO, WO, ST, and WT), (Figure 2.).

\begin{tabular}{|c|c|c|}
\hline & $\begin{array}{c}\text { Strengths } \\
(\mathrm{S}) \\
1 \\
\mathrm{n} \text {-th } \\
\text { (Obtained from IFE Matrix } \\
\end{array}$ & $\begin{array}{c}\text { Weaknesses } \\
(\mathrm{W}) \\
1 \\
\text { n-th } \\
\text { (Obtained from IFE matrix) } \\
\end{array}$ \\
\hline $\begin{array}{c}\text { Opportunities } \\
(\mathrm{O}) \\
1 \\
\mathrm{n}-\mathrm{th} \\
\text { (Obtained from EFE matrix }\end{array}$ & $\begin{array}{c}\text { S-O Strategies } \\
\text { Develop strategies that use the } \\
\text { strengths to capture opportunities }\end{array}$ & $\begin{array}{l}\text { WO Strategies } \\
\text { Develop strategies that minimize the } \\
\text { weaknesses to take advantage of an } \\
\text { opportunity }\end{array}$ \\
\hline $\begin{array}{c}\text { Threats } \\
(\mathrm{T}) \\
1 \\
\text { n-th } \\
\text { (Obtained from EFE matrix }\end{array}$ & $\begin{array}{l}\text { ST Strategies } \\
\text { Develop strategies that use the } \\
\text { strengths to cope with the threats }\end{array}$ & $\begin{array}{l}\text { WT Strategies } \\
\text { Develop strategies that minimize the } \\
\text { weaknesses to cope with the threats }\end{array}$ \\
\hline
\end{tabular}

Source: David (2009)

Figure 2.

Schematic illustration of SWOT Matrix

SWOT matrix preparation steps are described as follows: first, all of the external factors (opportunities and threats) and internal factors (strengths and weaknesses) of the EFE and IFE matrix are identified and included into the SWOT matrix. Then determining each factor, whether it belongs to the strength, weaknesses, opportunity or threat. This step is done by structuredquestionnaire and series of in-depth discussions with several experts. The experts are: former Minister of Agriculture Republic of Indonesia, Agricultural Economics lecturer, Chairman of the Department of
Nutrition and Livestock Production Hasanuddin University, Head of Production of Livestock Agency in South Sulawesi Province, Research Staff of Livestock Research Ciawi Bogor, Head Office of Livestock Research Ciawi Bogor, Head of Veterenary Departement of Institute Pertanian Bogor, and Livestock Agency of Barru Regency. Adjustments are then carried out between external and internal factors to produce and to formulate several alternative drafts of policy of on-farms beef cattle development in South Sulawesi. Among the adjustments are (i) matching the internal 
strengths with external opportunities (SO strategies), (ii) matching the internal weaknesses with external opportunities (WO strategy), (iii) matching the internal strengths with external threats (ST strategy), (iv) matching the internal weaknesses with external threats (WT strategy).

\subsection{QSPM (Qualitative Strategic Planning Matrix) Analysis}

David (2009) noted that QSPM is an instrument that allows strategists to evaluate alternative strategies objectively, based on the internal and external key success factors that have been identified. Like other instruments of strategy formulations, strategy formulation using QSPM method requires good intuitive judgment.

The decision stage is a stage to determine which strategy is feasible and the best alternative. It is done by using Quantitative Strategic Planning Matrix (QSPM). QSPM uses the analysis results of the input and matching phases. QSPM main components are: (i) the key factors, (ii) alternative strategies, (iii) weights, (iv) attractiveness Score (AS), (v) total attractiveness score (TAS), and (vi) sum total of Attractiveness Score.

Attractiveness score is obtained by determining the numeric score indicating the relative attractiveness of each strategy in particular alternative set. Attractiveness of the scores were assigned to each strategy to determine the relative attractiveness of one strategy over the other. On the contrary, the total attractiveness score is the score indicating a relative attractiveness of each alternative strategy that considers to be the impact of external and internal factors in that line. The higher the total score of attractiveness, the more attractive the alternative strategies will be.

Therefore QSPM indicates objectively best alternative strategies. It begins by determining the key success factors of the external environment from External Factor Evaluation (EFE) Matrix and finding the key success internal factors to cattle rancher from Matrix Internal Factor Evaluation (IFE) as the input of phase I. The next step is adjustment or phase II, such as (i) analising strengths, weaknesses, opportunities and threats using the SWOT matrix, (ii) analising combination of internal and external factors from Internal-External (IE) Matrix, and (iii) identifiying the position of the cattle ranchers under investigation in one of the existing quadrants. QSPM uses input from the result of analysis in phase I and phase II to determine objectively among alternative strategies existed or referred to as phase III.

\subsection{Framework}

The study begins by analysing the socio economics aspect of the cattle farmers. The result will provide our understanding on existing condition of cattle farmers in South Sulawesi. Our understanding on the existing condition of cattle farmers added by several planning documents become major inputs in developing IFE and EFE matrix for SWOT analysis and QSPM methods.

Beef cattle is a renewable natural resource, which are potential to economic improvement. Therefore further policies are needed for animal husbandry development through out intensification (procurement and improving the quality of cows, feed, disease control, credit and marketing as well as management system increasing economic production, use of quality cattle, feed and management).

Central Government has already launched several policies related to cattle development such as development programs for Beef Cattle Livestock Enterprises through an Integrated System of Livestock and Paddy (SIPT), Integrated System of Beef 
Cattle andPalm Plantation (SISKA), Program for Beef Cattle Optimization (GOS), Integrated Agribusiness Group (KUAT), Farming and Livestock Development in Eastern Indonesia (PUTKATI), Acceleration Program for Beef Self-Sufficiency (P2SDS),
Programs for Beef Cattle Population Achievement (PGP2S), and partnership schemes, All are expected to contribute significantly to the welfare of the farmers (based on who and what year) as seen in the Figure 3. below.

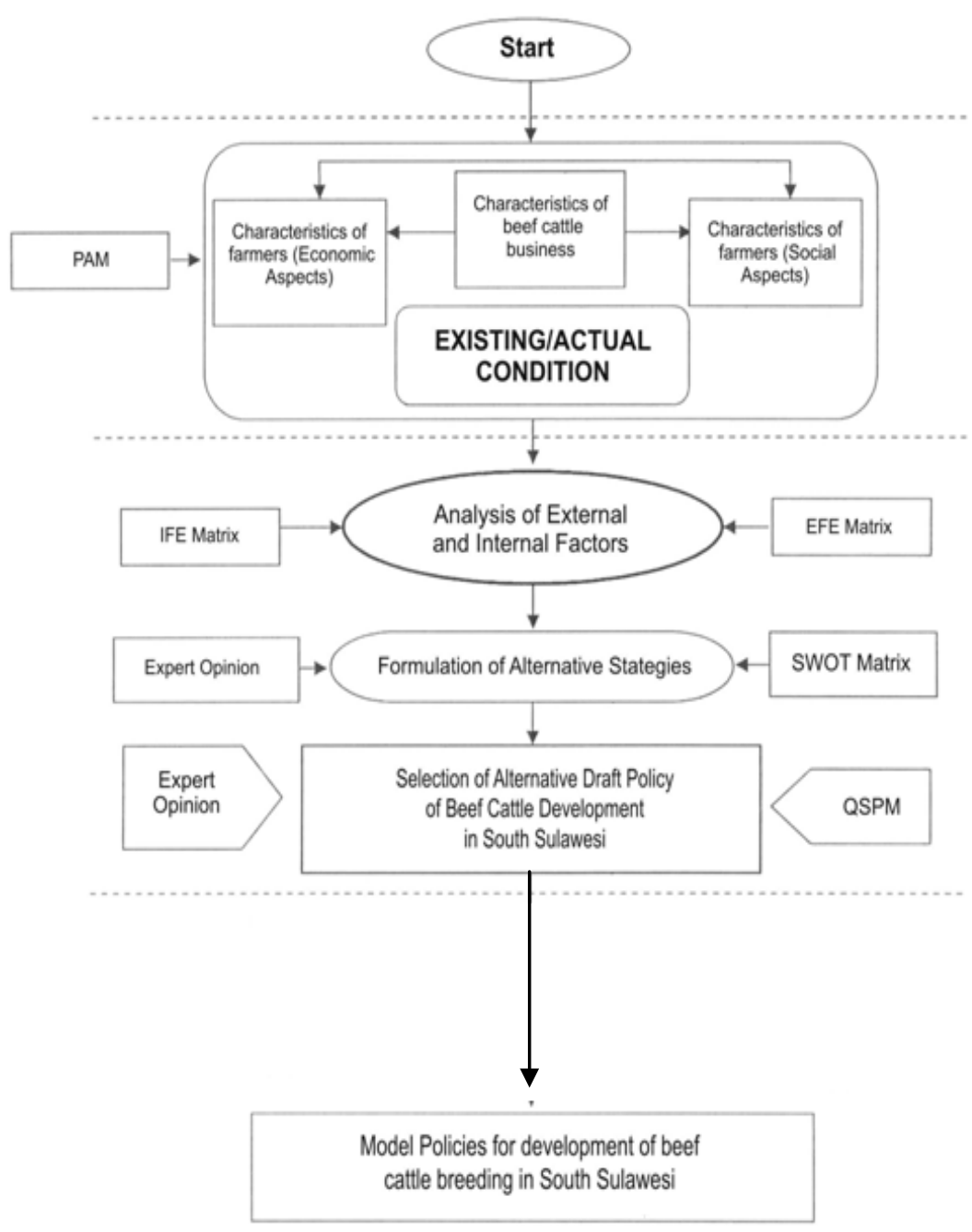

Figure 3.

Framework of the Study 


\section{RESEARCH METHOD}

This study uses two types of data, i.e primary and secondary data. Primary data were obtained from questionnaires, interviews and focus group discussions while secondary data were collected by conducting literature review to support, complete, and enhance primary data. Descriptive analysis is then used to obtain in-depth overview of the study object. To make ease the explanation of the results of this analysis, the information is presented in the form of tables, pictures, or matrix. The descriptive analysis in this study is used to describe the results of interviews and questionnaires regarding beef cattle development policies. Analysis of the above data is done by using SPSS software.

\section{RESULT AND DISCUSSION}

South Sulawesi is one of the production centers of beef cattle (983.985 cattle). It the third largest cattle barn in Indonesia after East Java Province $(4,727,298$ cattle) and Central Java $(1,937,551$ cattle) with total area for farming land $\pm 1,193,529$ ha based on existing economic conditions Most of the cattle farmers' age is between 20-50 years (70.50\%), and their educational background are mostly not finishing primary school and elementary graduates which reach up to $41.05 \%$. The average income of cattle farmers is IDR $3,000,000$ up to IDR $3,750,000$ per month. Average ownership of land area is 3.2 hectares per farmer used for fields, gardens, and other activities. The majority of beef cattle ownership in South Sulawesi is only 3 cattle for each farmer (34,68\%) (BPS, 2007).

Existing social conditions, shows that the frequency of the farmers to communicate with livestock counseling activity with Animal Husbandry Office is only once a year. Furthermore, based on the results obtained from the research, the overall farmers experience in managing beef cattle is less than five years $(35,7 \%)$, but they have very high motivation to develop and succeed the beef cattle business (41.65\%).

\subsection{Analysis on Internal and External Factors \\ 4.1.1 External Factor Evaluation (EFE Matrix)}

The Matrix External Factor Evaluations (EFE) was used to identify the value opportunity weight and threat for beef cattle producers in South Sulawesi. In Table 1. results show that government policy and programs have the highest value weight score of 0.082, compared to other external factors. It means that government plays an important role in supporting the development of beef cattle program in South Sulawesi. The total weight score, which is 3.487 , is higher than average score of effective strategy of 2.5 (David, 2009). It is meant that the strategies used are already effective using existing opportunity while minimizing threat. Animal husbandry development has new paradigms, namely alignment to people in general, responsibility delegation, structural change, and people empowerment. Therefore, it is necessary to formulate strategies and policies that are comprehensive, systematic, integrated-both vertically and horizontally-competitive, sustainable and decentralized. 
Table 1.

EFE Matrix (External Factor Evaluations)

\begin{tabular}{|c|c|c|c|}
\hline External Strategies Factor & Weight & Rating & Score \\
\hline \multicolumn{4}{|l|}{ Opportunities } \\
\hline $\begin{array}{l}\text { Improved knowledge of ranchers and technology } \\
\text { development }\end{array}$ & 0.072 & 3.88 & 0.280 \\
\hline Government support to develop beef cattle & 0.082 & 4.00 & 0.328 \\
\hline Develop opportunities to work & 0.061 & 3.88 & 0.236 \\
\hline Availability of sufficient transportation system & 0.058 & 3.13 & 0.182 \\
\hline "High potential feed availability & 0.077 & 3.98 & 0.335 \\
\hline Crop intensification with hay being used & 0.074 & 3.93 & 0.304 \\
\hline Increasing trend for beef consumption and demand & 0.067 & 3.50 & 0.234 \\
\hline Mutual benefit for partnership & 0.065 & 3.50 & 0.228 \\
\hline High number of population & 0.055 & 3.75 & 0.207 \\
\hline Total Opportunities & & & 2.335 \\
\hline \multicolumn{4}{|l|}{ Threats } \\
\hline Availability of imported product with higher beef quality & 0.063 & 3.00 & 0.188 \\
\hline High transportation cost & 0.060 & 2.75 & 0.179 \\
\hline Global marketing toward free marketing & 0.065 & 3.25 & 0.178 \\
\hline $\begin{array}{l}\text { Low bargaining position of beef cattle rancher which } \\
\text { reduces economic scale }\end{array}$ & 0.064 & 2.75 & 0.207 \\
\hline $\begin{array}{l}\text { Tendency of people with higher education to find work } \\
\text { else where }\end{array}$ & 0.061 & 2.63 & 0.168 \\
\hline Low level of cattle safeties & 0.077 & 2.63 & 0.203 \\
\hline Total Threats & & & 1.123 \\
\hline Total & 1.000 & & 3.457 \\
\hline
\end{tabular}

\subsubsection{Internal Factor Evaluation (IFE matrix)}

Internal Factor Evaluations (IFE) matrix is being used to determine the weight value for strength and weakness for internal factors affecting the development of beef cattle in South Sulawesi. From Table 2. it can be seen that the highest weight score is 0.666, which implies that factors that are effective are innovation, technology, maintenance and facilities. These factors are important internal factors, which are necessary to develop the beef cattle in South Sulawesi to support the food estate program. The result also shows that the sum of total weight score is 2.603. Therefore, it can be concluded that the strategy of developing beef cattle in South Sulawesi has been effective, using the strength and minimizing weaknesses which had contributed to negative impact.

Conclusions based on the analysis of strategy development formulation for cattle beef in South Sulawesi is that the famer needs to develop an integrated strategy involving cattle ranchers and crops (such as, rice and corn). This strategy can be achived by using potential raw materials for cattle feed. It is combined with government support (i.e. from central, province, or local governments) by adopting new developed 
technology or innovation, especially for feed processing.

Table 2.

IFE Matrix (Internal Factor Evaluations)

\begin{tabular}{|c|c|c|c|}
\hline Internal Strategies Factor & Weight & Rating & Score \\
\hline \multicolumn{4}{|l|}{ Strength } \\
\hline $\begin{array}{l}\text { Availability of local cattle which are adaptive and productive } \\
\text { (Bali cattle, cross PO) }\end{array}$ & 0.059 & 2.75 & 0.162 \\
\hline Availability of land and paddy/corn waste used for feed & 0.064 & 3.00 & 0.191 \\
\hline Availability of cattle facilities and maintenance & 0.066 & 2.67 & 0.176 \\
\hline $\begin{array}{l}\text { Government support from central, district or local consisting } \\
\text { developing programs (such as GOS, SIPT, PPBP, PUTKATI) }\end{array}$ & 0.065 & 2.83 & 0.185 \\
\hline High interest for cattle beef development from society & 0.056 & 2.50 & 0.140 \\
\hline Availability of cattle beef institutions as a leader & 0.052 & 2.58 & 0.135 \\
\hline Availability of flexibility technology innovations & 0.066 & 2.75 & 0.182 \\
\hline Availability of cattle beef groups & 0.054 & 2.75 & 0.148 \\
\hline Total Strength & & & 1.582 \\
\hline \multicolumn{4}{|l|}{ Weakness } \\
\hline Financial limitation for cattle beef ranchers & 0.064 & 1.92 & 0.123 \\
\hline Limitation of local cattle breed & 0.060 & 2.08 & 0.125 \\
\hline No coordination between institutions evolved & 0.050 & 1.67 & 0.084 \\
\hline Low knowledge and limitations for human resources & 0.063 & 1.58 & 0.100 \\
\hline Unavailability support from financial institutions & 0.058 & 1.67 & 0.096 \\
\hline Limitations of supporting institutions related to cattle beef & 0.055 & 1.92 & 0.105 \\
\hline Not optimized and inconsistency of programs related & 0.067 & 1.58 & 0.106 \\
\hline Uncoordinated marketing system & 0.053 & 1.50 & 0.080 \\
\hline Rancher's mind-set where cattle are as if saving product & 0.048 & 1.67 & 0.081 \\
\hline Total Weakness & & & 1.021 \\
\hline Total & 1.000 & & 2.603 \\
\hline
\end{tabular}

Suryana (2009) in his study also stated that in order to enhance the role of beef cattle as meat suppliers and livestock income sources, it is advisable to apply an intensive maintenance system with an improved feed management and improved quality of cattle with disease control. AI (Artifisial Insemination) and early weaning of calves to shorten the calving interval is needed to improve the reproduction. As for the improvement of genetic quality of the female calves, it is suggested to keep them in the breeding area for subsequent use as grading up cattle. Increased interest and motivation of cattle ranchers to expand their business can be facilitated through incentives in production.

\subsection{Mapping of Internal External Matrix (IE matrix)}

The EFE matrix and IFE matrix, which have been completed, are then being 
integrated into the external and internal matrices. These matrix shows the mapping or position of beef cattle development in South Sulawesi, considering the strength and weaknesses factors involved. Figure 4 . shows that based on weighted score and the evaluation of internal and external factors, the position for cattle beef development in South Sulawesi lies at the position of its growth and development (cell 2).

Based on the value of internal factors (2.603) and external factors (3.457), the government policy should be aimed at intensive programs, such as market penetration, market development, and developing products. Other government policies should also be aimed at integrating the programs such as backward integration, forward integration and product integration (David, 2009). In addition, the policy aimed at beef cattle development in South Sulawesi for food security program is highly required.

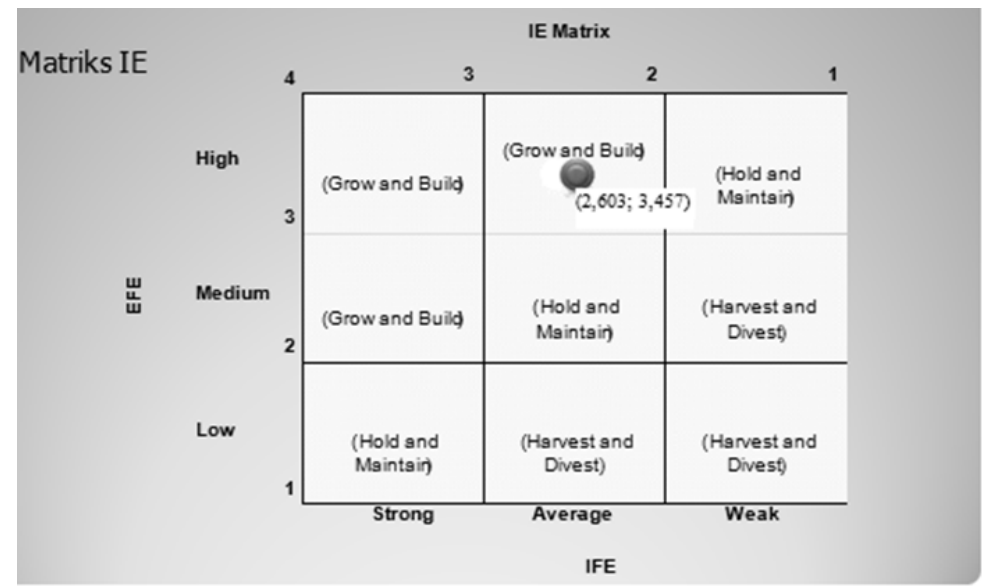

Figure 4.

Mapping of Internal External Matrix for beef cattle in South Sulawesi

An alternative incentive of government policy that can be implemented for product development in South Sulawesi, is product diversification. Diversification is a program involving processing meat, such as beef bacon, beef jerky, shredded beef, sausages or other tradition processed meat products. These types of programs could help local ranchers to improve their wellbeing and income. Integrated government policies could also develop an increase beef cattle program in South Sulawesi. An example would be a policy that integrates beef cattle with crops. The program involves using corn and rice waste, which are potential for cattle feed, using improved technology. Other government policies should be focus on the increasing development of beef cattle. The government may work with other stakeholders, companies, ranchers, or other local rancher groups.

\subsection{Formulating Strategies}

In order to formulate alternative strategies based on external and internal factors, these alternative strategies are being formulated using SWOT method. Expert opinions are also being used to formulate them which were then analysed based on factors of strength, weakness, opportunity 
and threat in conjunction with South Sulawesi problems faced by beef cattle development. The results can be seen on Table 3.

Table 3.

Matrix strategy development formulation for cattle beef in South Sulawesi

\begin{tabular}{|c|c|c|}
\hline OT & $\begin{array}{l}\text { Strength } \\
\text { 1) Availability of local cattle which are } \\
\text { adaptive and productive (Bali cattle, cross } \\
\text { PO) } \\
\text { 2) Availability of land and paddy/corn waste } \\
\text { used for feed } \\
\text { 3) Availability of cattle fasilities and } \\
\text { maintenance } \\
\text { 4) Goverment support from central, district } \\
\text { or local consisting developing programs } \\
\text { (such as GOS, SIPT, PPBP, PUTKATI, } \\
\text { etc) } \\
\text { 5) High interest for cattle beef development } \\
\text { from society } \\
\text { Availability of cattle beef institutions as a } \\
\text { leader } \\
\text { Availability of flexibility technology } \\
\text { innovations } \\
\text { 8) Availability of cattle beef groups } \\
\end{array}$ & $\begin{array}{l}\text { Weakness } \\
\text { 1) Financial limitation for cattle beef } \\
\text { ranchers } \\
\text { 2) Limitation of local cattle breed } \\
\text { 3) Uncoordination between intitutions } \\
\text { envolved } \\
\text { Low knowledge and limitations for } \\
\text { human resources } \\
\text { 5) Unavailability support from financial } \\
\text { intitutions } \\
\text { 6) Limitations of supporting institutions } \\
\text { related to cattle beef } \\
\text { Unoptimazed and inconsistency of } \\
\text { programs related } \\
\text { 8) Uncoordinated marketing system } \\
\text { 9) Rancher's mindset where cattle are } \\
\text { as if saving product }\end{array}$ \\
\hline 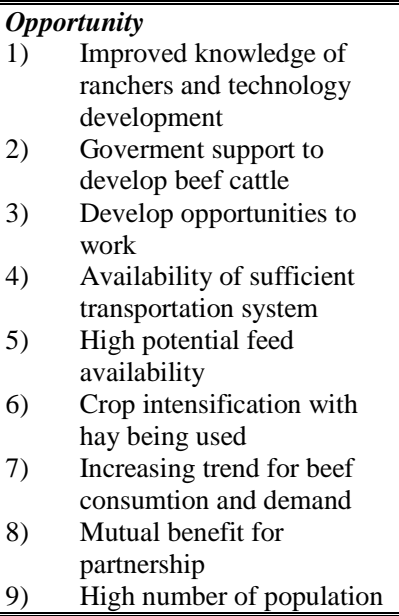 & $\begin{array}{l}\text { SO Strategies } \\
\text { SO 1. (S1,S2, S3,S4,O1,O2) } \\
\text { Developing an integration strategy involving } \\
\text { ranchers and crops (rice and corn). This can be } \\
\text { achived using potential raw materials for feed } \\
\text { with government support (central government, } \\
\text { province or local) by using new developed } \\
\text { technology or innovation specially for feed } \\
\text { processing }\end{array}$ & $\begin{array}{l}\text { WO Strategies } \\
\text { WO 1. (W3, W4, W5, O1, O2,O6) } \\
\text { Optimizing government role by supporting } \\
\text { programs which increase agribusiness } \\
\text { potential with an integration system, } \\
\text { increasing knowledge and ability of } \\
\text { ranchers by training programs and } \\
\text { assistance }\end{array}$ \\
\hline \begin{tabular}{ll}
\multicolumn{2}{l}{ Threat } \\
1) & $\begin{array}{l}\text { Availability of imported } \\
\text { product with higher beef } \\
\text { quality }\end{array}$ \\
2) & $\begin{array}{l}\text { High transportation cost } \\
\text { Global marketing toward } \\
\text { free marketing }\end{array}$ \\
4) & Low bargaining position of \\
beef cattle rancher which \\
reduces economic scale \\
T)
\end{tabular} & $\begin{array}{l}\text { ST Strategies } \\
\text { ST 1. (S1,S2,S3, S7, T1,T4,T6) } \\
\text { Increasing product and cattle quality and meat } \\
\text { through several technology innovations, } \\
\text { product diversification in order to increase } \\
\text { market target and increasing the role of safe } \\
\text { guards to guarantee the safetyness of cattle }\end{array}$ & $\begin{array}{l}\text { WT Strategies } \\
\text { WT. 1. (W1,W2, W3, W5, T1,T5,T6) } \\
\text { Limiting cattle import or products while } \\
\text { increasing the partnership with financial } \\
\text { institutions to increase rancher's finance. }\end{array}$ \\
\hline
\end{tabular}


Results using SWOT Matrix show four alternatives developing policy for cattle beef in South Sulawesi. These 4 quadranst analysis are considered to be a powerful tool to identify potential policies to be developed by ranchers in South Sulawesi. They are as follow:

a. Developing an integration strategy involving ranchers and crops (rice and corn). This can be achieved using potential raw materials for feed with government support (i.e. central, province, or local government) by adopting new developed technology or innovation specially for feed processing.

b. Increasing product and cattle quality and meat through several technology innovations, product diversification in order to increase market target and increasing the role of safe guards to guarantee the safeties of cattle.

c. Optimizing government role by supporting programs, which increase agribusiness potential with an integrated system, increasing knowledge and ability of ranchers by training and assistance programs.

d. Limiting cattle import or products while increasing the partnership with financial institutions to improve the access of rancher to financial institution.

\subsection{Choosing Priority Strategy}

QSPM (Quantitative Strategic Planning Matrix) is used in order to choose and determine which strategy is the best to recommend for cattle beef development in South Sulawesi. Based on SWOT Matrix analyses, these strategies are chosen to be implemented to the real condition of beef cattle.

The formulation of these strategies is based on interviews with the experts. Values given by experts are then calculated to find the whole score of all criteria's. The highest score will be the priority strategy. Table 4 . shows QSPM results.

From all four strategies, QSPM results shows that the first strategy or priority will be Strategy 1. Based on Total Alternative Strategy (TAS), the value from QSPM is 6,901. This priority strategy includes, increasing and developing a model between cattle beef and crop (paddy and corn), based on the potential availability of feed. This model should be supported by the government (central, district, or local) using advanced technology, which is aimed at feeding the innovation process.

Table 4.

QSPM Results for Choosing Priority Strategy

\begin{tabular}{|c|c|c|c|c|c|c|c|c|c|}
\hline \multirow{3}{*}{ Strategies Factor } & & \multicolumn{8}{|c|}{ Strategies } \\
\hline & \multirow{2}{*}{ weight } & \multicolumn{2}{|c|}{ Strategy I } & \multicolumn{2}{|c|}{ Strategy II } & \multicolumn{2}{|c|}{ Strategy III } & \multicolumn{2}{|c|}{ Strategy IV } \\
\hline & & AS & TAS & AS & TAS & AS & TAS & AS & TAS \\
\hline Strength & & & & & & & & & \\
\hline $\begin{array}{l}\text { Availability of local cattle } \\
\text { which are adaptive and } \\
\text { productive (Bali cattle, cross } \\
\text { PO) }\end{array}$ & 0.059 & 4 & 0.236 & 3 & 0.177 & 4 & 0.236 & 4 & 0.236 \\
\hline $\begin{array}{l}\text { Availability of land and } \\
\text { paddy/corn waste used for feed }\end{array}$ & 0.064 & 4 & 0.254 & 4 & 0.254 & 4 & 0.254 & 4 & 0.254 \\
\hline $\begin{array}{l}\text { Availability of cattle fasilities } \\
\text { and maintenance }\end{array}$ & 0.066 & 4 & 0.264 & 3 & 0.198 & 3 & 0.198 & 3 & 0.198 \\
\hline
\end{tabular}




\begin{tabular}{|c|c|c|c|c|c|c|c|c|c|}
\hline $\begin{array}{l}\text { Goverment support from } \\
\text { central, district or local } \\
\text { consisting developing programs } \\
\text { (such as GOS, SIPT, PPBP, } \\
\text { PUTKATI, etc) } \\
\end{array}$ & 0.065 & 4 & 0.261 & 4 & 0.261 & 4 & 0.261 & 4 & 0.261 \\
\hline $\begin{array}{l}\text { High interest for cattle beef } \\
\text { development from society }\end{array}$ & 0.056 & 4 & 0.225 & 3 & 0.168 & 3 & 0.168 & 3 & 0.168 \\
\hline $\begin{array}{l}\text { Availability of cattle beef } \\
\text { intitutions as a leader }\end{array}$ & 0.052 & 4 & 0.208 & 4 & 0.208 & 3 & 0.156 & 3 & 0.156 \\
\hline $\begin{array}{l}\text { Availability of flexibility } \\
\text { technology innovations }\end{array}$ & 0.066 & 4 & 0.264 & 4 & 0.264 & 4 & 0.264 & 4 & 0.264 \\
\hline $\begin{array}{l}\text { Availability of cattle beef } \\
\text { groups }\end{array}$ & 0.054 & 3 & 0.162 & 4 & 0.216 & 3 & 0.162 & 3 & 0.162 \\
\hline Weakness & & & & & & & & & \\
\hline $\begin{array}{l}\text { Financial limitation for cattle } \\
\text { beef ranchers }\end{array}$ & 0.064 & 4 & 0.256 & 3 & 0.192 & 3 & 0.192 & 3 & 0.192 \\
\hline Limitation of local cattle breed & 0.06 & 4 & 0.240 & 4 & 0.240 & 4 & 0.240 & 4 & 0.240 \\
\hline $\begin{array}{l}\text { Uncoordination between } \\
\text { intitutions envolved }\end{array}$ & 0.05 & 4 & 0.202 & 4 & 0.202 & 3 & 0.151 & 3 & 0.151 \\
\hline $\begin{array}{l}\text { Low knowledge and limitations } \\
\text { for human resources }\end{array}$ & 0.063 & 4 & 0.253 & 3 & 0.189 & 3 & 0.189 & 3 & 0.189 \\
\hline $\begin{array}{l}\text { Unavailability support from } \\
\text { financial intitutions }\end{array}$ & 0.058 & 3 & 0.173 & 4 & 0.230 & 3 & 0.173 & 3 & 0.173 \\
\hline $\begin{array}{l}\text { Limitations of supporting } \\
\text { institutions related to cattle beef }\end{array}$ & 0.055 & 3 & 0.164 & 4 & 0.219 & 3 & 0.164 & 3 & 0.164 \\
\hline $\begin{array}{l}\text { Unoptimazed and inconsistency } \\
\text { of programs related }\end{array}$ & & & & & & & & & \\
\hline $\begin{array}{l}\text { Uncoordinated marketing } \\
\text { system }\end{array}$ & 0.067 & 4 & 0.267 & 4 & 0.267 & 4 & 0.267 & 4 & 0.267 \\
\hline $\begin{array}{l}\text { Rancher's mindset where cattle } \\
\text { are as if saving product }\end{array}$ & 0.053 & 3 & 0.160 & 3 & 0.160 & 4 & 0.213 & 4 & 0.213 \\
\hline Weakness & 0.048 & 3 & 0.145 & 3 & 0.145 & 3 & 0.145 & 3 & 0.145 \\
\hline \multicolumn{10}{|l|}{ Opportunities } \\
\hline $\begin{array}{l}\text { Improved knowledge of } \\
\text { ranchers and technology } \\
\text { development }\end{array}$ & 0.072 & 4 & 0.290 & 4 & 0.290 & 4 & 0.290 & 4 & 0.290 \\
\hline $\begin{array}{l}\text { Goverment support to develop } \\
\text { beef cattle }\end{array}$ & 0.082 & 4 & 0.328 & 4 & 0.328 & 4 & 0.328 & 4 & 0.328 \\
\hline Develop opportunities to work & 0.061 & 4 & 0.244 & 2 & 0.122 & 2 & 0.122 & 2 & 0.122 \\
\hline $\begin{array}{l}\text { Availability of sufficient } \\
\text { transportation system }\end{array}$ & 0.058 & 3 & 0.174 & 3 & 0.174 & 3 & 0.174 & 3 & 0.174 \\
\hline High potential feed availabili & 0.077 & 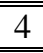 & 0.307 & 4 & 0.307 & 4 & 0.307 & 4 & 0.307 \\
\hline
\end{tabular}




\begin{tabular}{|c|c|c|c|c|c|c|c|c|c|}
\hline $\begin{array}{l}\text { Crop intensification with hay } \\
\text { being used }\end{array}$ & 0.074 & 4 & 0.295 & 4 & 0.295 & 4 & 0.295 & 4 & 0.295 \\
\hline $\begin{array}{l}\text { Increasing trend for beef } \\
\text { consumtion and demand }\end{array}$ & 0.067 & 3 & 0.201 & 3 & 0.201 & 3 & 0.201 & 3 & 0.201 \\
\hline Mutual benefit for partnership & 0.065 & 3 & 0.195 & 4 & 0.260 & 3 & 0.195 & 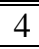 & 0.260 \\
\hline High number of population & 0.055 & 2 & 0.110 & 2 & 0.110 & 3 & 0.166 & 2 & 0.110 \\
\hline \multicolumn{10}{|l|}{ Threats } \\
\hline $\begin{array}{l}\text { Availability of imported } \\
\text { product with higher beef quality }\end{array}$ & 0.063 & 3 & 0.188 & 3 & 0.188 & 4 & 0.250 & 3 & 0.188 \\
\hline High transportation cost & 0.060 & 3 & 0.179 & 3 & 0.179 & 3 & 0.179 & 3 & 0.179 \\
\hline $\begin{array}{l}\text { Global marketing toward free } \\
\text { marketing }\end{array}$ & 0.065 & 2 & 0.130 & 3 & 0.194 & 3 & 0.194 & 3 & 0.194 \\
\hline $\begin{array}{l}\text { Low bargaining position of beef } \\
\text { cattle rancher which reduces } \\
\text { economic scale }\end{array}$ & 0.064 & 3 & 0.191 & 3 & 0.191 & 3 & 0.191 & 3 & 0.191 \\
\hline $\begin{array}{l}\text { Tendency of people with higher } \\
\text { education to find work else } \\
\text { where }\end{array}$ & 0.061 & 3 & 0.183 & 3 & 0.183 & 2 & 0.122 & 3 & 0.183 \\
\hline 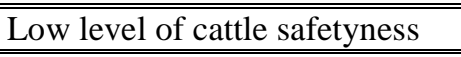 & 0.077 & 2 & 0.155 & 3 & 0.232 & 4 & 0.310 & 3 & 0.232 \\
\hline Total & & & 6.901 & & 6.844 & & 46.757 & & 46.687 \\
\hline
\end{tabular}

These findings are consistent with results from Ananto (2011) which suggested that strategies should be integrated in order to succeed. Furthermore, in his research he concluded that there are some pre-requisites for the fulfilment of an integrated plan for self-sufficiency in beef production: (i) trading system which is conducive to the creation of value-added livestock industry, (ii) defined policy of sectorial farm program, and (iii) the availability of budget for cowcalf operation, breeding and the development of the breeding areas. As for the implementation phase, the institutions that play most significant roles are Coordinating Ministry for Economic Affairs, together with the Ministry of Agriculture and Ministry of Commerce (Ananto et.al., 2011).

Another strategy to support the development of beef cattle business in South Sulawesi is the establishment of a partnership between governments, companies, and local cattle ranchers or groups.The partnership in this context is meant as a collaboration between agribusiness which is starting form the process of pre-production, production to marketing that is based on mutual need and mutual benefit principles (Saptana et.al, 2006) . This concept should be a comprehensive farm business, ranging from subsistence production, production process, product, to marketing (Suryana, 2009). The format or the partnership model that can be applied in the beef cattle business development in South Sulawesi is a model of cooperation within Agribusiness Operations (KOA). In this model, groups of partners provide the land, infrastructure and facilities, and workforce, while the others provide capital and/or infrastructure/tools to cultivate an agricultural commodity. Partner companies can be in the form of main company or supervisory companies which is responsible for land clearing, providing land or with seeds, farming or breeding, or having self-managed units. The main company is also implementing a 
management development in technology, the means of production, capital or credit, product processing, accommodate production, and markets the product of its partners.

\section{CONCLUSION RECOMMENDATIONS}

AND

The study shows that the condition of cattle beef development in South Sulawesi is very promising. The 9 cell-SWOT analysis concludes that based on weighted score and the evaluation of internal and external factors, the position for cattle beef development in South Sulawesi lies at the position of its growth and development. Therefore, government policies should focus on increasing and developing cattle beef programs, incentives and supporting policies. Furthermore, based on interviews with experts on strength, weakness, opportunity and threat factors, four strategies were then being formulated in order to develop the cattle beef in South Sulawesi. From these four strategies, QSPM matrix results show that the first strategy or priority strategy will be Strategy 1. This strategy has the highest value compared to other strategies, based on Total Alternative Strategy (TAS). This priority strategy includes increasing and developing a model between cattle beef and crop (paddy and corn), based on the potential availability of feed. This model should be supported by the government (central, district, or local) using advanced technology, which is aimed at feeding the innovation process.

This study recommends that the government should play more active role, especially those institutions that are involved directly with the cattle beef programs. There should be an integrated, coordinated and consistent programs. The institutions related to cattle beef rancher should be more aggressive in recruiting and maintaining ranchers. However, the study also recommends that the government should continue the existing programs. 


\section{DAFTAR PUSTAKA}

Ananto N, Eriyatno, Marimin, Arief D. 2011. Integration For Planning Livestock Development Model.

Amar AL. 2008. “Grass Feed Availability Strategy To Develop Cattle Beef In South Sulawesi”. Journal for Agriculture Research and Development 24 (1): 72-79.

Badan Pusat Statistik. 2007. www.bps.go.id. [diakses 13 Februari].

Bamualim AM, B Trisnamurti, C Thalib. 2008. “Arah Pengembangan Sapi Potong di Indonesia”. Jurnal Litbang Pertanian 12 (2): 22-28.

Bamualim A \& Tresnamurti B, 2009. Sistem Integrasi Ternak Tanaman : Padi, Sawit, Kakao. Pusat Penelitian dan Pengembangan Peternakan. Badan Penelitian dan Pengembangan Pertanian. Konsepsi Sistem Integrasi Antara Tanaman Padi, Sawit, dan Kakao dengan Ternak Sapi di Indonesia.

Dwiyanto K, A. Priyanti \& Ismeth Inounu. 2005. Prospek dan arah pengembangan komoditas peternakan : Unggas, sapi dan kambing-domba. Wartazoa, hal 11-25

Dwiyanto K. 2008. "Pemanfaatan sumber daya lokal dan inovasi teknologi dalam mendukung pengembangan sapi potong di Indonesia”. Pengembangan Inovasi Pertanian. 1(3):173-188

Daryanto A. 2009. Competition Dynamics For The Livestock Industry. IPB Press. Bogor

David Fred R. 2006. Manajemen Strategis. Ed ke-10. Budi, Ichsan Setiyo, Penerjemah. Jakarta: Salemba Empat. Terjemahan dari: Strategic Management.

David J. 2009. Strategic Management: Manajemen Strategis: Konsep 12th edition. Terjemahan oleh Dono Sunardi. Jakarta: Salemba Empat.

Haryanto B dan Yulistiani D, 2009. “Teknologi Pengayaan Pakan Sapi Terintegrasi dengan Tanaman Padi”. Sistem Integrasi Ternak Tanaman: Padi - Sawit - Kakao

Hendricson J. 2008. "Interactions in integrated US agricultural systrems”. The past, present and future Renewable Agriculture and Food Sistems: 314-324

Nasution, A. 1983. Studi Evaluasi Pengembangan Ternak dan Kerbau. Forum Penelitian Agro Ekonomi Vol. 2. No.1. Pusat Penelitian Sosial Ekonomi Pertanian. Bogor

Nugrohadi IAW. 2009.” Analisis Kebijakan Agribisnis”. Bahan Kuliah Program Doktor Manajemen Bisnis IPB Angkatan 4. [Tidak diterbitkan].

Nugroho BA. 2006. "Livestock Agribusiness Development Support For The Productive Economics (Study at North Sulawesi)”. Journal For Agriculture Research and Development (16): 62-72.

Rahardi FR, dan Hartono. 2003. Agribisnis Peternakan. Jakarta: Penebar Swadaya.

Santosa U. 2006.” Pengembangan Sapi Bali dalam Manajemen Ternak”. Jurnal Litbang Pertanian 22 (2): $34-40$

Saragih , B. 2000. Livestock -Based Agribusiness. Pustaka Wirausaha Bogor.

Siagian. 2004. Manajemen Strategi. Jakarta: PT Bumi Aksara.

Suryana. 2009. "Development Of The Cattle Beef Business Agribusiness Based With The Partnership System”. Journal For Agriculture Research and Development 28 (1) : 29-37.

Saptana, et al (2006).” Mewujudkan Keunggulan Komparatif Menjadi Keunggulan Kompetitif Melalui Pengembangan Kemitraan Usaha Hortikultura”. Forum Penelitian Agro Ekonomi. 24 (1). (61-76)

Suryana. 2009. Pengembangan Usaha Ternak Sapi Potong Berorientasi Agribisnis dengan Pola Kemitraan. Jurnal Litbang Pertanian 28(1):29-37. 